\title{
PERILAKU KONSUMSI MEDIA PADA PRIA DI SURABAYA (Studi pada Upaya Peningkatan Partisipasi KB Pria)
}

\author{
Hilda Yunita Wono ${ }^{1 *}$, Monika Teguh ${ }^{2}$ \\ Universitas Ciputra, Surabaya \\ * Penulis korespondensi; Email: hilda.yunita@ciputra.ac.id
}

\begin{abstract}
ABSTRAK
Kepadatan penduduk di Surabaya menyebabkan Pemerintah Kota Surabaya harus mengambil langkah strategis guna meningkatkan partisipasi masyarakat pada program Keluarga Berencana (KB). Saat ini program KB sudah banyak dijalankan oleh kalangan wanita, namun sayangnya KB Pria masih jarang diminati. Hal ini disebabkan oleh adanya mitosmitos yang keliru maupun ketidaktahuan masyarakat mengenai jenis KB ini. Padahal jenis KB ini relatif lebih aman dan mudah pelaksanaannya. Perilaku konsumsi media digunakan untuk menemukan media yang tepat digunakan untuk sosialisasi serta membenahi pemikiran mengenai KB Pria. Dengan menggunakan mixed methods research ditemukan Facebook dan web portal adalah media yang yang paling sering digunakan sasaran KB Pria di Surabaya.
\end{abstract}

Kata kunci: Perilaku konsumsi media, media sosialisasi, KB pria, Surabaya.

\begin{abstract}
The population density in Surabaya drives Surabaya city government to take strategic steps to strengthen public participation in Family Planning program. Currently family planning program is choosen by mostly women, but unfortunately it is not popular between the male users. This is caused by misleading myths and public ignorance regarding this type for birth control, even though it is relatively safer and easier to implement. That is why in this research, media consumption behaviour is used to find the right media for socialization and improving the knowledge about Family Planning for male users. This research method that used in this study is mixed methods and the result shows Facebook and web portal are the most commonly used by male targets in Surabaya.
\end{abstract}

Keywords: Media consumption behaviour, media, contraception for men, Surabaya.

\section{PENDAHULUAN}

Tercatat sampai dengan akhir 2015, penduduk Surabaya sudah mencapai angka 2.848 .583 jiwa (BPS Jatim, 2016). Jumlah penduduk ini masih terus meningkat dengan angka pertumbuhan penduduk sebesar 0.63 (Pemerintah Kota Surabaya, 2015), padahal sejak tahun 2010 kepadatan penduduk di Surabaya sudah melebihi batas. Jumlah penduduk yang begitu besar menjadikan Surabaya sebagai kota terbesar kedua di Indonesia dengan jumlah penduduknya. Menurut data dari Dispendukcapil, jumlah penduduk ideal untuk kota Surabaya adalah 75 orang per hektar. Namun nyatanya pada tahun 2010 saja sudah terdapat 87 orang penduduk per hektar (Kristanti, 2010). Hal ini tentunya akan membawa dampak negatif bagi penduduk kota Surabaya. Luqman dan Kwardiniya dalam salah satu tulisan ilmiahnya menjelaskan bahwa penduduk yang tinggal di wilayah yang terlalu padat harus berkompetisi untuk bertahan hidup (Khaqim \& Andawaningtyas, 2013). Kompetisi ini akan berlangsung dalam hal pemenuhan kebutuhan dasar seperti sandang, pangan, papan, pendidikan, maupun pekerjaan yang berujung pada meningkatnya kriminalitas dan menurunnya kesejahteraan warga.

Melihat kondisi ini, Pemerintah Kota Surabaya sudah mulai menggalakkan kembali program Keluarga Berencana (KB) melalui Badan Pemberdayaan Masyarakat dan Keluarga Berencana (Bapemas KB). Program KB ini berperan dalam penanggulangan masalah kesehatan reproduksi yang pada ujungnya akan mendorong terbentuknya keluarga cerdas dan berkualitas. Ada beberapa metode KB untuk wanita yaitu intrauterine device (IUD), Mantap Medis Operatif Wanita (MOW) atau Tubektomi, Implant atau Susuk, Sutik, dan Pil, serta untuk Pria dengan metode Mantap Medis Operatif Pria (MOP) atau Vasektomi dan Kondom. Menurut data dari Bapemas $\mathrm{KB}$, penggunaan $\mathrm{KB}$ pada wanita sudah cenderung tinggi, namun $\mathrm{KB}$ Pria masih rendah peminat. Penggunaan KB Pria terutama metode Vasektomi pada tahun 2015 hanya $0,26 \%$ dari seluruh pengguna KB di Surabaya. Peningkatannya dari tahun ke tahun pun cenderung rendah yaitu dari tahun 2013 ke tahun 
2014 meningkat sebanyak 38\% dan malah menurun lagi di tahun 2015 sebanyak 10\% (Bapemas KB Surabaya, 2016).

Hal ini perlu mendapat perhatian khusus, karena pada praktiknya banyak pasangan tidak melakukan KB karena istri mengalami gangguan kesehatan seperti menderita tekanan darah tinggi, diebetes, penyakit jantung, penyakit paru-paru, pendarahan vaginal, infeksi sistemik atau pelvik, dan alergi. Maka dari itu alternatif bagi pasangan tersebut adalah menggunakan KB Pria. Namun yang menjadi masalah adalah pengetahuan masyarakat masih rendah, sehingga muncul mitos bahwa KB Pria sama dengan kebiri. Hal ini juga diperparah dengan terbatasnya tenaga dokter yang menindaklanjuti KB Pria. Bapemas KB hanya mempunyai 6 dokter dari Dinas Kesehatan dan 5 orang asisten dokter dari BKKBN yang menangani sekitar 1500 peserta KB setiap tahunnya. Dengan kondisi tersebut, tenaga kesehatan yang ada tidak lagi memiliki waktu dan kesempatan untuk melakukan sosialisasi lebih lanjut. Maka dari itu perlu dipikirkan cara sosialisasi lain yang dapat menjangkau masyarakat agar dapat mengenal KB Pria dengan baik serta menghilangkan mitos-mitos tidak benar mengenai KB Pria.

Dalam jurnal penelitian Faktor Penyebab Rendahnya Jumlah Pria Menjadi Akseptor Keluarga Berencana dijelaskan bahwa yang menjadi faktor dominan adalah pengetahuan masih kurang oleh para pria mengenai KB pria (Surinati, Mayuni, \& Putra, 2015). Hal ini memperkuat peneliti merumuskan cara sosialisasi yang tepat, maka diperlukan pemahaman lebih lanjut mengenai perilaku pria di Surabaya dalam menggunakan media penyampaian pesan. Oleh karena itu perlu dilaksanakan analisis perilaku penggunaan media dalam upaya meningkatkan partisipasi KB Pria. Dengan diketahuinya perilaku penggunaan media pada pria, akan lebih mudah merumuskan strategi sosialisasi untuk peningkatan partisipasi $\mathrm{KB}$ Pria. Bagi Pemerintah Kota Surabaya, penelitian ini bisa menjadi dokumen panduan dalam pengambilan kebijakan pemilihan media dalam meningkatkan Partisipasi KB terutama bagi kaum pria.

\section{TINJAUAN PUSTAKA}

\subsection{Media}

Media berasal dari bahasa Latin yang berarti perantara atau pengantar. Beberapa ahli menjelaskan lebih lanjut mengenai pengertian dari media. Schram menjelaskan bahwa media merupakan teknologi pembawa pesan. Hal ini dijelaskan lebih lanjut oleh Heinich bahwa media merupakan teknologi perantara antara sumber yang memberi pesan dengan penerima pesan. Contohnya adalah film, televisi, cetakan, komputer, dan hal-hal lain yang mampu menyalurkan suatu pesan dari satu orang kepada orang lain (Susilana \& Riyana, 2009).

Pada dasarnya media menjalankan dua fungsi utama, yaitu fungsi penyampai informasi dan fungsi penghibur. Contoh dari fungsi penyampai informasi adalah ketika ingin mengetahui berita terbaru dan mendapatkannya dari koran atau berita di televisi. Sedangkan fungsi penghibur adalah seperti ketika kita sedang menonton film, mendengarkan musik, maupun bermain game di internet. Kedua fungsi ini tidak dapat dipisahkan dari kehidupan manusia dimana manusia setiap hari memerlukan informasi maupun hiburan. Ditambah lagi dengan perkembangan zaman, dimana manusia cenderung menjadi semakin sibuk dan memiliki banyak keinginan, maka peran media dalam kehidupan juga semakin berkembang. Teknologi juga membuat media menjadi semakin banyak jenis dan fungsinya, sehingga manusia dalam kesehariannya pasti terkoneksi oleh suatu media. Bahkan dapat dikatakan kehidupan masyarakat modern sama sekali tidak terlepas dari media. Sejak bangun tidur sampai dengan kembali tidur, seseorang selalu terpapar media dalam berbagai bentuk. Maka dari itu keberadaan media menjadi vital bagi kehidupan manusia (Katz, 2014).

Secara umum terdapat beberapa penggolongan jenis media. Salah satunya media dibedakan menurut bentuknya menjadi media cetak dan media elektronik. Media cetak merupakan segala media dalam bentuk tercetak seperti koran, majalah, billboards, surat, buku, brosur dan lain-lain. Sedangkan media elektronik adalah sesuatu yang diaplikasikan dalam perangkat elektronik seperti televisi, radio, komputer dan handphone. Dalam perkembangannya media diklasifikasikan berdasarkan kepemilikan menjadi tiga jenis yaitu media berbayar (paid media), media milik pribadi (owned media), dan media yang didapatkan (earned media). Media berbayar adalah jenis media dimana pengirim pesan harus membayar sejumlah dana agar pesannya dapat ditampilkan dimedia tersebut. Contohnya adalah televisi, radio, koran, majalah, baliho, dan situs iklan di internet. Sedangkan media milik pribadi adalah media yang dimiliki dan dikelola sendiri oleh sumber pesan, contohnya adalah website perusahaan, packaging produk, newsletter internal, dan brosur. Sedangkan media yang didapatkan adalah media yang umumnya 
gratis, namun memerlukan usaha dan pengorbanan untuk mengelolanya agar mendapatkan perhatian dari banyak orang. Contohnya adalah media sosial atau organic search pada mesin pencari (Katz, 2014). Ahli lain menggolongkan media menjadi media analog dan media digital. Media analog memiliki wujud fisik, dimana penyaluran pesan dilakukan melalui transkripsi dari satu bentuk fisik ke bentuk fisik lainnya. Sedangkan media digital berwujud serangkaian deretan angka biner yang dapat berubah-ubah dan disimpan dalam memori komputer atau cloud (Lister, Dovey, Giddings, Grant, \& Kelly, 2009).

\subsection{Pendekatan Penggunaan dan Kepuasan (Uses and Gratification)}

Teori yang populer digunakan untuk melihat pengguna media dibandingkan dengan pesan yang disampaikan. Pendekatan teori penggunaan dan kepuasan ini berfokus pada perilaku audiens dalam pengalaman langsung penggunaan media (Littlejohn \& Foss, 2014). Pendekatan ini memandang bahwa komunikan sebagai pengguna media yang aktif memilih media yang mereka inginkan sesuai dengan tujuan mereka menggunakan media tersebut. Melalui pendekatan ini media dianggap sebagai satu-satunya faktor pemenuhan kebutuhan oleh audiens yang diasumsikan mereka tahu kebutuhannya dan bagaimana memenuhi kebutuhan tersebut.

Bagi audiens yang ingin mencari tahu mengenai suatu hal, mereka secara aktif akan melakukan pemilihan media untuk memuaskan kebutuhannya. Misalnya saja jika sesorang membutuhkan informasi, maka ia dapat memilih untuk membaca surat kabar, menonton siaran televisi, mendengarkan radio, atau menggunakan media apa pun yang menurutnya dapat memenuhi kebutuhannya akan informasi. Hal inipun juga terjadi pada audiens yang melakukan pemilihan penggunaan media untuk memenuhi kebutuhan akan hiburan dan lain sebagainya. Dengan kata lain, audiens atau komunikan menggunakan media karena didasari oleh motif tertentu. Perbedaan pola dalam pemilihan media pada akhirnya menuju pada perbedaan pola terpaan suatu media media serta efek yang ditimbulkan.

\subsection{Perilaku Konsumsi Media}

Secara umum perilaku konsumen dapat didefinisikan sebagai interaksi dinamis antara kognisi dan afeksi, perilaku, serta lingkungan dimana seseorang melakukan pertukaran aspek-aspek dalam kehidupannya. Maka dari itu dapat dipahami jika perilaku seseorang dalam mengonsumsi suatu produk melibatkan pikeran, perasaan, dan kebiasaan mereka. Selain itu lingkungan juga sangat berpengaruh dalam perilaku konsumen dimana komentar orang lain, trend dimasyarakat dan perubahan sosial juga turut mempengaruhi hal tersebut (Peter \& Olson, 2005). Disini perlu kita pahami bahwa media merupakan salah satu produk konsumsi masyarakat, maka dari itu masyarakat juga memiliki perilaku konsumsi yang unik terhadap media. Perilaku ini dapat dipelajari dan ditemukan polanya sehingga dapat menjadi acuan untuk merancang program-program berbasis media. Perilaku konsumsi dari masyarakat dapat dianalisis menggunakan kerangka sebagai berikut:

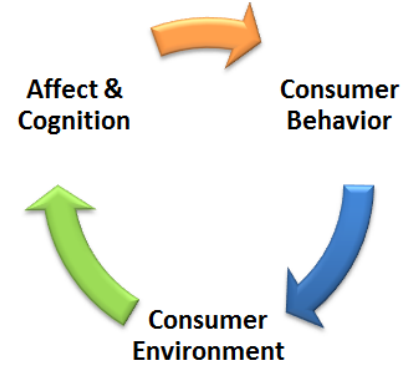

Gambar 1. Aspek-Aspek Dalam Perilaku Konsumsi

Berdasarkan bagan diatas dapat dilihat bahwa analisis konsumen dilakukan melalui tiga aspek yaitu afeksi dan kognisi, perilaku atau kebiasaan konsumen, dan lingkungan tempat konsumen berinteraksi. Afeksi dan kognisi adalah respon mental yang ditunjukkan oleh konsumen terhadap suatu rangsangan. Secara khusus afeksi akan membahas mengenai perasaan mereka terhadap sesuatu, sedangkan kognisi akan membahas tentang pemikiran dan kepercayaan mereka. Perilaku atau kebiasaan konsumen adalah serangkaian kegiatan fisik yang dapat diobservasi secara langsung oleh orang lain. Kebiasaan ini menjadi penting karena ini merupakan perwujudan dari pemikiran dan perasaan seseorang yang nampak nyata. Yang terakhir, lingkungan konsumen adalah segala sesuatu diluar diri konsumen yang mempengaruhi bagaimana mereka berpikir, merasa dan bertindak. Hal ini mencakup rangsangan sosial seperti budaya, kelas sosial, kelompok acuan, dan keluarga yang mempengaruhi konsumen.

\section{METODE PENELITIAN}

Penelitian ini secara spesifik akan digunakan metode campuran (mixed methods research). Dalam metode ini digabungkan dua jenis pendekatan yaitu pendekatan kualitatif dan kuantitatif (Bryman, 2008). Pada penggunaan metode campuran, peneliti bisa memilih untuk mengumpulkan data dengan pendekatan 
kualitatif atau kuantitatif terlebih dahulu bergantung pada tujuan penelitian. Jika tujuan penelitian adalah untuk mengeksplorasi dimana belum ada data-data terkait sebelumnya, maka dapat dilakukan pendekatan kualitatif terlebih dahulu kemudian dilanjutkan dengan pendekatan kuantitatif untuk meraih sampel yang lebih luas (Tashakkori \& Teddlie, 2003). Maka dari itu dalam penelitian ini akan digunakan metode campuran yang dimulai dengan pendekatan kualitatif dan dilanjutkan dengan pendekatan kuantitatif.

Pendekatan kualitatif digunakan untuk memahami fenomena secara natural dan mendalam, dimana peneliti akan menggali, menyemai dan menelisik halhal kecil untuk memperoleh data yang spesifik (Daymon \& Holloway, 2008). Untuk dapat melakukannya peneliti akan berinteraksi secara dekat dengan informan untuk dapat menggali sudut pandang mereka dalam kehidupan sehari-hari. Kriteria informan yang dipilih adalah pria yang berusia antara 1549 tahun, sudah menikah dengan usia istri minimal 24 tahun, sudah memiliki anak minimal satu orang, dan masing-masing tinggal di wilayah kecamatan Semampir, Kenjeran, Tambaksari, Sawahan, atau Wonokromo. Wilayah-wilayah tersebut dipilih karena merupakan wilayah dengan penetrasi KB Pria paling rendah di Surabaya. Dari sini diharapkan peneliti akan dapat mengetahui perilaku penggunaan media dalam kehidupan sehari-hari informan, serta jenis-jenis media yang paling banyak mempengaruhi kehidupan mereka.

Setelah diketahui jenis-jenis media yang digunakan oleh informan, akan dicari preferensi dari sasaran KB Pria di Surabaya yang lebih luas menggunakan pendekatan kuantitatif. Pendekatan kuantitatif adalah metode penelitian yang didasarkan pada informasi numerik atau kuantitas-kuantitas, dan umumnya dianalisis dengan statistik (Stokes, 2007). Pendekatan ini perlu digunakan karena adanya sifat generalizability, dimana hasil penelitian dapat diberlakukan secara luas dalam latar dan populasi yang sejenis (Daymon \& Holloway, 2008). Populasi dari penelitian ini adalah pria, berdomisili di Surabaya, berusia 15-49 tahun, sudah menikah, memiliki anak minimal satu orang dan dalam kondisi sehat untuk mengikuti program KB Pria. Dikarenakan jumlah populasi yang tidak diketahui, maka sampel penelitian ini diambil berdasarkan teori Fraenkel dan Wallen (1993) yang menyarankan untuk penelitian jenis deskriptif dapat terwakili dengan minimum 100 responden. Teknik pengambilan sampel menggunakan purposive sampling dimana peneliti memilih responden berdasarkan kriteria tertentu yang dapat mendukung tujuan penelitian. Adapun kriteria dari responden dalam penelitian ini adalah pria berusia 15-49 tahun, berdomisili di Surabaya, sudah menikah, memiliki anak minimal satu orang dan dalam kondisi sehat untuk mengikuti program KB Pria Metode ini diharapkan mampu menggambarkan secara obyektif preferensi media bagi sasaran KB Pria berdasarkan data-data yang dikumpulkan. Dengan demikian akan dapat menjadi acuan penyusunan strategi pemilihan media bagi program KB Pria yang dapat digunakan dengan lebih menyeluruh bagi masyarakat Surabaya.

\section{HASIL DAN PEMBAHASAN}

\subsection{Perilaku Penggunaan Media Pria di Surabaya}

Berdasarkan hasil wawancara dengan informan yang ditemui, media massa masih merupakan salah satu cara utama untuk memperoleh informasi. Selain media massa, media below the line seperti brosur dan poster juga masih dimanfaatkan untuk memperoleh informasi tambahan walaupun tidak sesering media massa. Penyampaian informasi antar personal juga masih berlangsung dalam berbagai kegiatan informal seperti obrolan saat jam istirahat kantor maupun perkumpulan warga. Adapun dalam penelitian ini akan lebih difokuskan pada media dengan biaya terjangkau yang mampu menjangkau publik dengan pesan yang cenderung seragam, sehubungan dengan kondisi dan kebutuhan sosialisasi program KB Pria.

Media massa utama yang saat ini menjadi pilihan oleh para audiens atau khususnya informan adalah internet. Media baru ini digunakan karena kemudahannya untuk mengakses informasi, banyaknya sumber yang tersedia, kecepatan pembaharuan informasi, dan juga biaya yang cenderung murah. Selain itu, sifat informasi dari internet bisa memenuhi kebutuhan information on demand, dimana para informan dapat mencari informasi yang mereka butuhkan kapanpun dimanapun. Hal ini mereka umumnya lakukan dari mesin pencari seperti google. Informasi yang mereka percaya umumnya adalah yang dikeluarkan oleh situs-situs atau portal berita seperti merdeka.com, detik.com, kompas.com, dan tempo.com. Selain itu, para informan juga tertarik dengan informasi yang viral di media sosial seperti Facebook. Informasi yang disebarkan oleh teman atau muncul di halaman Facebook mereka dapat mendorong para informan ini untuk mencari tahu lebih lanjut tentang hal tersebut. Maka dari itu, web portal berita dan media sosial Facebook perlu menjadi media yang dipertimbangkan untuk sosialisasi KB Pria. 
Selain internet, media massa konvensional yang masih sering digunakan oleh para informan sampai saat ini adalah radio, koran dan TV. Mereka memanfaatkan media ini terutama untuk mengisi waktu luang dan memperoleh informasi. Kekurangan dari media massa konvensional ini jika diterapkan untuk program sosialisasi KB Pria adalah adanya sejumlah biaya yang harus dikeluarkan serta konten yang muncul tidak bisa on demand atau menyajikan informasi sesuai kebutuhan dari masyarakat. Namun kredibilitas dan jangkauan dari media massa konvensional bisa sangat membantu sosialisasi program. Karena keterbatasan yang dimiliki oleh penyelenggara program sosialisasi KB Pria, maka media massa konvensional yang dapat dipertimbangkan adalah koran dan radio.

Selain media massa, untuk mencari informasi yang jauh lebih mendetil para informan masih menggunakan media below the line seperti brosur dan poster. Jika dibandingkan dengan poster, brosur dapat memuat lebih banyak informasi yang mendetil. Selain itu brosur juga dapat dibawa pulang untuk dibaca kembali dibandingkan poster. Maka dari itu brosur dapat menjadi pertimbangan media untuk memberikan informasi yang lebih mendetil dalam sosialisasi program KB Pria.

\subsection{Preferensi Media Untuk KB Pria}

Dari hasil analisis mengenai media tersebut, ditemukan bahwa informan cenderung menggunakan Facebook, web portal berita, koran, radio, dan brosur. Tahap selanjutnya dalam penelitian ini adalah melakukan survey dengan kuisioner untuk menemukan preferensi media yang paling diminati dalam mencari berita kepada 100 responden pria di Surabaya. Hasil survei kemudian diolah menggunakan statistik dan menghasilkan data sebagai berikut:

Tabel 1. Analisis Statistik Deskriptif Preferensi Media Descriptives

\begin{tabular}{l|c|r|r|r|r|r}
\hline \multicolumn{1}{l|}{ Penilaian Media } & & & & & & \\
& \multicolumn{1}{c|}{$\mathrm{N}$} & Minimum & Maximum & Mean & Std. Deviation & Std. Error \\
\hline Faceb0ok & 100 & 1.0 & 5.0 & 3.540 & 1.5204 & .1520 \\
Web Portal & 100 & 1.0 & 5.0 & 3.560 & 1.3052 & .1305 \\
Radio & 100 & 1.0 & 5.0 & 2.740 & 1.2195 & .1220 \\
Koran & 100 & 1.0 & 5.0 & 2.970 & 1.2015 & .1201 \\
Brosur & 100 & 1.0 & 5.0 & 2.190 & 1.3461 & .1346 \\
Total & 500 & 1.0 & 5.0 & 3.000 & 1.4156 & .0633 \\
\hline
\end{tabular}

Berdasarkan tabel 1 dapat dilihat bahwa jumlah kuesioner yang dianalisis adalah 100 buah dengan nilai peringkat paling kecil 1 dan paling besar 5. Dari hasil analisis data ditemukan standar deviasi yang berkisar antara 1,20-1,52. Standar deviasi ini menunjukkan bahwa data yang diberikan oleh responden cenderung tidak berbeda terlalu jauh satu sama lain. Data diatas juga menunjukkan standar error yang berkisar di 0,06 - 0,15. Hal ini menunjukkan bahwa data yang diperoleh peneliti valid karena angka standar error berada diatas 0,05 .

Sedangkan preferensi media yang dipilih oleh responden dapat dilihat dari nilai mean. Mean tertinggi yaitu 3,560 terdapat pada atribut Web Portal, sehingga web portal menjadi preferensi utama media bagi sasaran program. Berikutnya mean tertinggi kedua dengan nilai tidak jauh dari yang pertama yaitu 3,540 terdapat pada atribut Facebook. Hal ini menunjukkan bahwa Facebook juga menjadi salah satu media yang dipilih bersamaan dengan web portal. Pada praktiknya memang Facebook dapat digunakan untuk menyebarkan konten-konten dari web portal, demikian pula berita di web portal dapat dibagikan oleh pengguna melalui akun Facebook sehingga penggunaan kedua media ini dapat berkesinambungan.

Media dengan mean diurutan ketiga adalah koran dengan nilai 2,970. Kemudian pada urutan keempat adalah radio dengan nilai 2,740. Sedangkan brosur menjadi preferensi terakhir dengan nilai mean 2,190. Hal ini menunjukkan bahwa meskipun bukan merupakan preferensi utama, media-media ini masih digunakan oleh para responden. Media ini dapat dijadikan sebagai media-media penunjang untuk memberikan informasi yang lebih detil atau sebagai peningkat kredibilitas dari berita yang disebarkan melalui web portal dan Facebook.

\section{KESIMPULAN}

Saat ini penetrasi penggunaan KB Pria di wilayah Surabaya masih tergolong rendah. Data menunjukkan pelaku KB Pria pada tahun 2015 hanya 0,26\% dari seluruh pengguna KB di Surabaya. Peningkatannya dari tahun ke tahun pun cenderung rendah bahkan sempat menurun di tahun 2015. Adapun kondisi ini disebabkan karena minimnya informasi yang diperoleh masyarakat tentang KB Pria. Hal tersebut juga diperparah dengan mitos-mitos tidak benar seperti KB Pria sama dengan kebiri dan berbahaya bagi pria. Berawal dari permasalahan ini, Bappeko, Bapemas $\mathrm{KB}$, dan Bagian Bina Program Pemerintah Kota Surabaya akan merancang program sosialisi bagi KB Pria.

Agar program tersebut dapat disampaikan dengan baik, diperlukan pemahaman terlebih dahulu menge- 
nai preferensi terhadap media yang digunakan oleh warga pria di Surabaya yang menjadi sasaran sosialisasi. Hal ini bertujuan untuk dapat melakukan pemilihan media yang sesuai demi keberhasilan program. Maka dari itu dilaksanakan penelitian untuk menganalisis perilaku penggunaan media pada pria di Surabaya. Penelitian dilaksanakan dengan menggunakan metode kualitatif untuk menemukan media apa yang umum digunakan untuk mencari berita, kemudian dilanjutkan dengan metode kuantitatif untuk mengetahui preferensi masyarakat terhadap rumusan penggunaan media secara general.

Dari hasil yang didapatkan dirumuskan media yang sering digunakan yaitu Facebook, web portal, radio, koran, dan brosur. Dari kelima media tersebut web portal dan Facebook menjadi pilihan utama dalam penggunaan media untuk mencari berita ataupun informasi. Sedangkan koran, radio dan brosur dapat menjadi media penunjang untuk menyampaikan pesan-pesan yang lebih mendetil atau meningkatkan kredibilitas informasi tentang KB Pria.

Perkembangan teknologi informasi yang sangat cepat dapat membuat masyarakat pun cepat berubah dalam penggunaan media untuk mencari berita. Setelah diketahui preferensi media bagi sosialisasi program KB Pria, maka disarankan pihak penyelenggara program dapat segera merancang program kerja sosialisasi. Adapun rancangan program kerja dapat dibuat berdasarkan rekomendasi yang dicantumkan juga dalam penelitian ini. Setelah mendapatkan media yang sering digunakan oleh para pria, penelitian selanjutnya diharapkan dapat menemukan pesan yang tepat dalam menyampaikan pengetahuan mengenai $\mathrm{KB}$ pria.

\section{DAFTAR PUSTAKA}

Bapemas KB. (2016). Jumlah Tenaga Medis Untuk Pelayanan KB di Surabaya. Surabaya: Bapemas KB.

Bapemas KB Surabaya. (2016). Jumlah Peserta KB Aktif Tahun 2012-2015. Surabaya: Bagian Kesejahteraan Rakyat Pemerintah Kota Surabaya.

BPS Jatim. (2016). Jumlah Penduduk Tahun 20112015. Retrieved November 23, 2016, from Badan Pusat Statistik Provinsi Jawa Timur:
http://jatim.bps.go.id/linkTableDinamis/view/id/ 12

Bryman, A. (2008). Social Research Methods (3rd Edition). Oxford: Oxford University Press.

Daymon, C., \& Holloway, I. (2008). Metode-Metode Riset Kualitatif dalam Public Relations dan Marketing Communication. Yogyakarta: Penerbit Bentang.

Fraenkel, J., \& Wallen, N. (1993). How to Design and Evaluate Research in Education 2nd Edition. New York: McGraw-Hill Inc.

Katz, H. (2014). The Media Handbook. New York: Routledge.

Khaqim, L., \& Andawaningtyas, K. (2013). Proyeksi Penduduk Provinsi DKI Jakarta dan Kota Surabaya dengan Model Pertumbuhan Logistik. Jurnal Mahasiswa Matematika 1, no.3 , 232.

Kristanti, E. Y. (2010, September 27). Surabaya Kelebihan Penduduk 800 Ribu Orang. Retrieved July 09, 2016, from Viva Nasional: http://nasional.news.viva.co.id/news/read/178010-surabayaobesitas-800-ribu-jiwa

Lister, M., Dovey, J., Giddings, S., Grant, I., \& Kelly, K. (2009). New Media A Critical Introduction. New York: Routledge.

Littlejohn, S. W., \& Foss, K. A. (2014). Teori Komunikasi Edisi 9. Jakarta: Salemba Humanika.

Pemerintah Kota Surabaya. (2015). Informasi Data Pokok Surabaya Tahun 2015. Surabaya: Dinas Komunikasi dan Informatika Kota Surabaya.

Peter, J. P., \& Olson, J. C. (2005). Consumer Behaviour and Marketing Strategy. New York: McGraw-Hill/Irwin .

Stokes, J. (2007). How to Do Media and Cultural Studies. Yogyakarta: PT Bentang Pustaka.

Surinati, I. D., Mayuni, I. G., \& Putra, I. K. (2015). Faktor Penyebab Rendahnya Jumlah Pria Menjadi Akseptor Keluarga Berencana. Gema Keperawatan, 1-6.

Susilana, R., \& Riyana, C. (2009). Media Pembelajaran - Hakikat, Pengembangan, Pemanfaatan dan Penilaian. Bandung: CV Wacana Prima.

Tashakkori, A., \& Teddlie, C. (2003). Handbook of Mixed Methods in Social and Behavioral Research. California: Sage Publications, Inc.

West, R., \& Turner, L. H. (2008). Pengantar Teori Komunikasi, Analisis dan Aplikasi. Jakarta: Salemba Humanika. 